\title{
Chlamydia trachomatis, Mycoplasma genitalium, Mycoplasma hominis, and Ureaplasma spp. Coinfection in an HIV-Positive Homosexual Man
}

\author{
Swati Khullar ${ }^{1}$ Jyoti Rawre ${ }^{1}$ Deepika Yadav² Neena Khanna² Benu Dhawan ${ }^{1}$ \\ ${ }^{1}$ Department of Microbiology, All India Institute of Medical Sciences, \\ New Delhi, India \\ ${ }^{2}$ Department of Dermatology and Venereology, All India Institute of \\ Medical Sciences, New Delhi, India \\ Address for correspondence Benu Dhawan, MD, Department of \\ Microbiology, All India Institute of Medical Sciences, Ansari Nagar, \\ New Delhi, 110029, India (e-mail: dhawanb@gmail.com).
}

J Lab Physicians 2021;13:380-383.

\begin{abstract}
Keywords

- coinfection

- men who have sex with men

- extragenital STIS

A 21-year-old human immunodeficiency virus-positive male patient presented with complaints of multiple hyperpigmented verrucous papules over his perianal area. He reported having unprotected anal and oral sex with multiple male partners. On examination, superficial ill-defined perianal erosions were present. A first void urine sample and clinician-collected rectal and oropharyngeal swabs were sent for the detection of Chlamydia trachomatis, Mycoplasma genitalium, Mycoplasma hominis, and Ureaplasma spp. Rectal swab tested positive for all the four pathogens. Oropharyngeal swab and urine samples tested positive for $C$. trachomatis. The patient was treated with doxycycline and moxifloxacin. This case underscores the importance of screening of men who have sex with men for possible coinfections with multiple sexually transmitted pathogens.
\end{abstract}

\section{Introduction}

Men who have sex with men (MSM) are considered at high risk of sexually transmitted infections (STIs). Agents like Chlamydia trachomatis and genital mycoplasmas can potentially influence and increase the acquisition and transmission of other STIs including human immunodeficiency virus (HIV). ${ }^{1}$

Coinfection of $C$. trachomatis with either Mycoplasma hominis, Ureaplasma spp., or Mycoplasma genitalium has been reported in literature. ${ }^{2-4}$ We report a case of coinfection of these four pathogens in an HIV-positive MSM.

\section{Case Report}

A 21-year-old male patient presented to the STI clinic with complaints of multiple hyperpigmented verrucous papules over his perianal area for the previous 3 months, previously managed at a private hospital by local podophyllum application, to which he had partially responded. The patient did not give any history of genital ulcer or urethral discharge. $\mathrm{He}$ gave sexual history of homosexual behavior and reported having unprotected anal and oral sex with multiple male partners. The patient was HIV-positive and already on TLE regimen (tenofovir + lamivudine + efavirenz) with a baseline CD4 count of 475 . On clinical examination, superficial ill-defined perianal erosions were present at the sites of podophyllum application. There were no lesions or inflammation in the rectum. He did not have any active genital warts or lymphadenopathy. Examination of the oral cavity revealed pharyngeal congestion.

Laboratory records revealed that the patient was seronegative for hepatitis B (HbsAg), hepatitis C, and syphilis (VDRL). Microscopic examination of Gram-stained smear published online June 28, 2021
DOI https://doi.org/

10.1055/s-0041-1731119

ISSN $0974-2727$ (c) 2021. The Indian Association of Laboratory Physicians.

This is an open access article published by Thieme under the terms of the Creative Commons Attribution-NonDerivative-NonCommercial-License, permitting copying and reproduction so long as the original work is given appropriate credit. Contents may not be used for commercial purposes, or adapted, remixed, transformed or built upon. (https://creativecommons.org/licenses/by-nc-nd/4.0/).

Thieme Medical and Scientific Publishers Pvt. Ltd. A-12, 2nd Floor, Sector 2, Noida-201301 UP, India 
of the urethral swab revealed two to three pus cells per oil-immersion field and no gram-negative intracellular diplococci were seen. A first void urine sample and rectal and oropharyngeal swabs were sent for the detection of $C$. trachomatis and genital mycoplasmas. In-house polymerase chain reaction (PCR) was performed for $C$. trachomatis targeting cryptic plasmid ( - Table $\mathbf{1}$ ). Briefly, the $25 \mu \mathrm{L}$ reaction mixture contained $2.5 \mu \mathrm{L}$ of $10 \times$ PCR buffer (1× PCR buffer is $10 \mathrm{mmol} / \mathrm{L} \mathrm{Tris}-\mathrm{HCl}\left[\mathrm{pH} 8.8\right.$ at $\left.25^{\circ} \mathrm{C}\right], 1.5 \mathrm{mmol} / \mathrm{L} \mathrm{MgCl}_{2}$ $50 \mathrm{mmol} / \mathrm{L} \mathrm{KCl}$, and $0.1 \%$ Triton X-100), $200 \mu \mathrm{mol} / \mathrm{L}$ (each) deoxynucleoside triphosphate (dNTPs) mixture, $10 \mathrm{pmol}$ of each primer, $2 \mathrm{U}$ of Taq DNA polymerase, $5 \mu \mathrm{L}$ of sample DNA, and ultrapure sterile water. In-house PCR for M. genitalium targeting the $140 \mathrm{kDa}$ adhesion gene was performed (-Table 1). The $25 \mu \mathrm{L}$ reaction mixture contained $2.5 \mu \mathrm{L}$ of $10 \times \mathrm{PCR}$ buffer $(1 \times \mathrm{PCR}$ buffer is $10 \mathrm{mmol} / \mathrm{L}$ Tris- $\mathrm{HCl}[\mathrm{pH} 8.8$ at $\left.25^{\circ} \mathrm{C}\right], 50 \mathrm{mmol} / \mathrm{L} \mathrm{KCl}$, and $0.1 \%$ Triton $\mathrm{X}-100$ ), $4.5 \mathrm{mM} \mathrm{MgCl}_{2}$, $1 \mathrm{U}$ of Taq polymerase, $250 \mu \mathrm{mol} / \mathrm{L}$ (each) dNTPs mixture, 20 pmol of each primer, $5 \mu \mathrm{L}$ of sample DNA, and ultrapure sterile water. Multiplex PCR was performed for urease gene of Ureaplasma spp. and 16S rDNA of M. hominis (-Table 1). Briefly, the $50 \mu \mathrm{L}$ reaction mixture contained $5 \mu \mathrm{L}$ of $10 \times \mathrm{PCR}$ buffer $\left(1 \times\right.$ PCR buffer is $10 \mathrm{mmol} / \mathrm{L}$ Tris- $\mathrm{HCl}\left[p \mathrm{H} 8.8\right.$ at $\left.25^{\circ} \mathrm{C}\right]$,
$50 \mathrm{mmol} / \mathrm{L} \mathrm{KCl}$, and $0.1 \%$ Triton X-100), $3.0 \mathrm{mM} \mathrm{MgCl} 2,1.25 \mathrm{U}$ Taq polymerase, $400 \mu \mathrm{mol} / \mathrm{L}$ (each) dNTPs, $25 \mathrm{pmol}$ of each primer, $16 \mu \mathrm{L}$ of sample DNA, and ultrapure sterile water.

A negative control in the form of template free master mix solution was included in each run of amplification. To eliminate the cross-contamination and thereby to overcome false-positives, before amplification master mix containing nuclease-free water, Taq Buffer B, $\mathrm{MgCl}_{2}$ and Taq DNA polymerase were incubated for 15 minutes with $0.1 \mathrm{IU}$ of uracil $\mathrm{N}$-glycosylase enzyme. After incubation, dNTP mix and primers were carried out in a final master mix.

The rectal swab tested positive for all the four pathogens. However, oropharyngeal swab and urine sample tested positive for $C$. trachomatis alone (-Figs 1-3).

The patient was treated with oral doxycycline $100 \mathrm{mg}$ twice daily for 7 days. However, in view of decreased efficacy of doxycycline in M. genitalium infection, moxifloxacin 400mg was given once daily for another 7 days. Partner treatment could not be done as the patient was not willing to inform his partners about his condition. However, he was advised abstinence during the treatment period. Posttreatment, patient's first void urine sample and rectal and oropharyngeal swabs tested negative for all the four pathogens. There were no new

Table 1 Details of PCR assays for detection of Chlamydia trachomatis and genital mycoplasmas

\begin{tabular}{|c|c|c|c|c|c|}
\hline Organism & Target & Primer sequence & \multicolumn{3}{|c|}{ Cycling conditions } \\
\hline \multirow[t]{3}{*}{$\begin{array}{l}\text { Chlamydia } \\
\text { trachomatis }\end{array}$} & \multirow[t]{3}{*}{$\begin{array}{l}\text { Cryptic } \\
\text { plasmid }\end{array}$} & \multirow[t]{3}{*}{$\begin{array}{l}\text { KL1 5'-TCCGGAGCGAGTTACGAAGA-3' } \\
\text { KL2 5'-AATCAATGCCCGGGATTGGT-3' }\end{array}$} & Denaturation & $\begin{array}{l}94^{\circ} \mathrm{C} \\
\text { for } 1 \\
\min \end{array}$ & \multirow[t]{3}{*}{35 cycles } \\
\hline & & & Annealing & $\begin{array}{l}55^{\circ} \mathrm{C} \\
\text { for } 2 \\
\min \end{array}$ & \\
\hline & & & Extension & $\begin{array}{l}72^{\circ} \mathrm{C} \\
\text { for } 1 \\
\min \end{array}$ & \\
\hline \multirow[t]{4}{*}{$\begin{array}{l}\text { Mycoplasma } \\
\text { genitalium }\end{array}$} & \multirow[t]{4}{*}{ Adhesin gene } & \multirow[t]{4}{*}{$\begin{array}{l}\text { MgPa1 5'- AGTTGTGAAACCTTAACCCTTGG-3' } \\
\text { MgPa3 5'-CCGTTGAGGGGTTTTCCATTTTTGC-3 }\end{array}$} & $\begin{array}{l}\text { Initial } \\
\text { denaturation }\end{array}$ & $\begin{array}{l}95^{\circ} \mathrm{C} \\
\text { for } 1 \\
\min \end{array}$ & \\
\hline & & & Denaturation & $\begin{array}{l}95^{\circ} \mathrm{C} \\
\text { for } 1 \\
\min \end{array}$ & \multirow[t]{3}{*}{35 cycles } \\
\hline & & & Annealing & $\begin{array}{l}67^{\circ} \mathrm{C} \\
\text { for } 15 \\
\text { sec }\end{array}$ & \\
\hline & & & Extension & $\begin{array}{l}72^{\circ} \mathrm{C} \\
\text { for } 6 \\
\min \end{array}$ & \\
\hline \multirow[t]{4}{*}{$\begin{array}{l}\text { Ureaplasma spp. } \\
\text { M. hominis }\end{array}$} & \multirow[t]{4}{*}{$\begin{array}{l}\text { Urease, } \\
\text { 16S rDNA } \\
\text { (Multiplex) }\end{array}$} & \multirow{4}{*}{$\begin{array}{l}\text { U4 5'-ACGACGTCCATAAGCAACT-3' } \\
\text { U5 5'-CAATCTGCTCGTGAAGTAATTAC-3' } \\
\text { RNAH1 5'-CAATGGCTAATGCCGGATACGC-3' } \\
\text { RNAH2 5'-GGTACCGTCAGTCT-3' }\end{array}$} & $\begin{array}{l}\text { Initial } \\
\text { denaturation }\end{array}$ & $\begin{array}{l}95^{\circ} \mathrm{C} \\
\text { for } 10 \\
\min \end{array}$ & \\
\hline & & & Denaturation & $\begin{array}{l}95^{\circ} \mathrm{C} \\
\text { for } 15 \\
\text { sec }\end{array}$ & \multirow[t]{3}{*}{35 cycles } \\
\hline & & & Annealing & $\begin{array}{l}60^{\circ} \mathrm{C} \\
\text { for } 1 \\
\min \end{array}$ & \\
\hline & & & Extension & $\begin{array}{l}72^{\circ} \mathrm{C} \\
\text { for } 5 \\
\min \end{array}$ & \\
\hline
\end{tabular}

Abbreviation: PCR, polymerase chain reaction. 


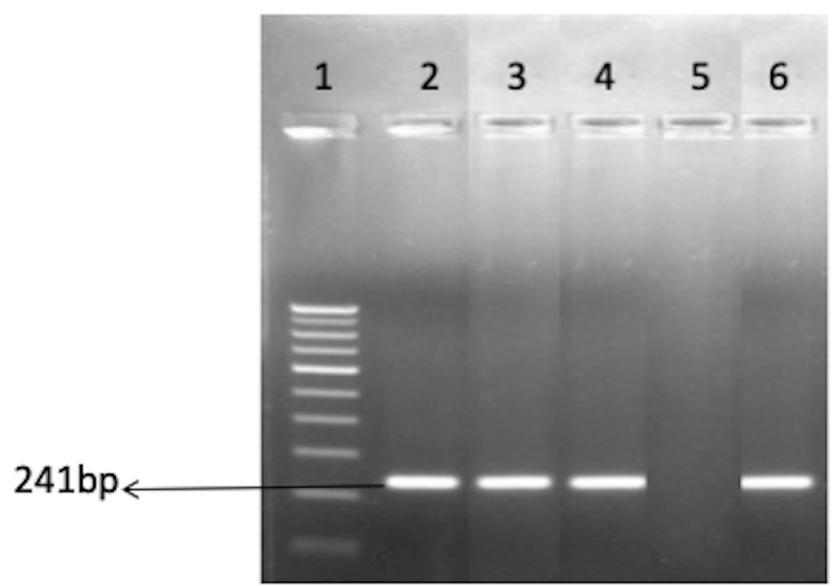

Fig. 1 Gel electrophoresis picture of the polymerase chain reaction for Chlamydia trachomatis targeting cryptic plasmid and ompA gene. Lane 1, 100 bp ladder; Lane 2, urine sample (positive); Lane 3, rectal swab (positive); Lane 4, oropharyngeal swab (positive); Lane 5, negative control; Lane 6, positive control (ATCC VR-885).

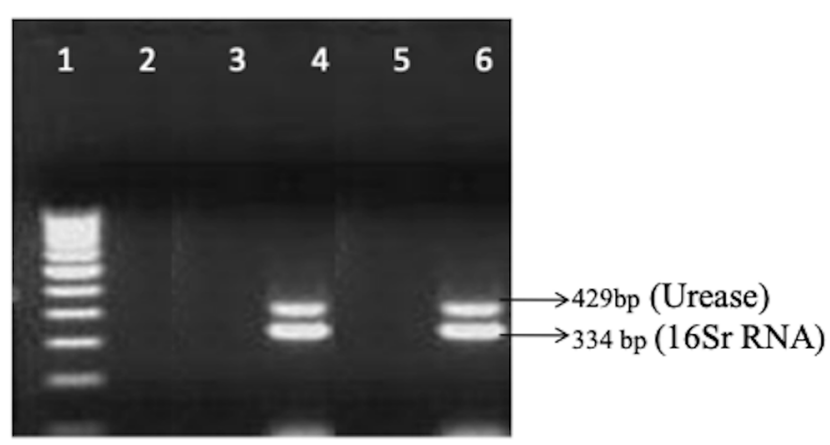

Fig. 3 Gel electrophoresis picture of the multiplex-polymerase chain reaction for Ureaplasma spp. and Mycoplasma hominis targeting urease gene and $16 \mathrm{~S}$ ribosomal DNA, respectively.Lane 1, 100 bp ladder; Lane 2, negative control; Lane 3, urine sample (negative); Lane 4, rectal swab (positive for Ureaplasma and $M$. hominis); Lane 5, oropharyngeal swab (negative); Lane 6, positive control (Ureaplasma NCTC 10177, urease positive; M. hominis NCTC 10111, 16 S rRNA positive).

genital complaints and the patient was counselled for safe sex practices.

\section{Discussion}

Genital mycoplasmas and C. trachomatis have commonly been implicated as copathogens in HIV-infected patients. Presence of one agent warrants testing for other sexually transmitted organisms especially in high-risk patients. Extragenital sites are believed to serve as hidden reservoirs for ongoing transmission of infection and their treatment is also different compared to that of genital infection. Most MSMs report bisexual behavior and such patients can act as a bridge population in spreading various STIs. ${ }^{5}$

Extragenital STIs especially rectal infections are often asymptomatic. In a study, Foschi et al reported $63.1 \%$ asymptomatic rectal infections due to $C$. trachomatis, Neisseria

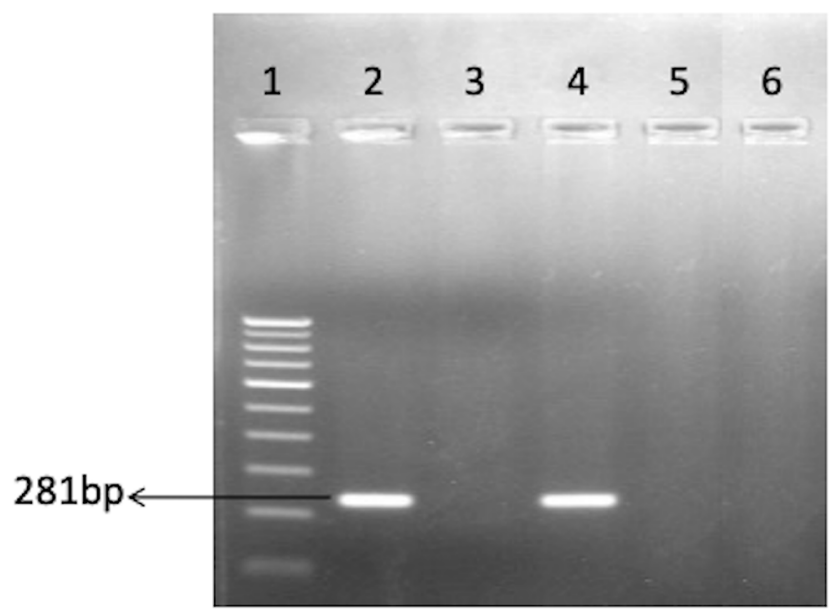

Fig. 2 Gel electrophoresis picture of the polymerase chain reaction for Mycoplasma genitalium targeting adhesion gene.Lane 1, 100 bp ladder; Lane 2, positive control; Lane 3, urine sample (negative); Lane 4, rectal swab (positive); Lane 5, oropharyngeal swab (negative); Lane 6, negative control.

gonorrhoeae, and M. genitalium in MSMs and that $80 \%$ of these infections would have gone undetected in absence of rectal site testing. ${ }^{6}$ Our patient also had asymptomatic rectal infection. Infection with Ureaplasma, M. hominis, M. genitalium, and $C$. trachomatis would have been missed had rectal sample not been tested. Hence, extragenital screening becomes vital due to the asymptomatic nature of these infections.

The MSM population can be exposed to these pathogens in a number of ways making a detailed sexual history and thorough clinical examination crucial in such patients. Centers for Disease Control and Prevention recommends annual screening of all MSMs for syphilis, chlamydia, and gonorrhea, 3 to 6 monthly screening of MSMs with persisting high-risk behavior with multiple partners. ${ }^{7}$ PCR is a preferred approach for screening of these patients. Although cultures have historically been the gold standard, they are subjective and PCR offers to be a more sensitive and specific testing modality.

Ureaplasma has been reported to cause non-gonococcal urethritis, prenatal infections and complications during pregnancy. Ureaplasma offers a survival advantage for $C$. trachomatis by disturbing the genital tract homeostasis. ${ }^{8,9}$ However, there are no guidelines for the screening or testing of Ureaplasma spp. or Mycoplasma spp. in extragenital sites.

M. genitalium infections are reported to present as coinfections. Pépin et al showed that almost half of the M. genitalium infections were coinfections. In their study, the prevalence of coinfection of $M$. genitalium with $N$. gonorrhoeae, C. trachomatis, and Trichomonas vaginalis was 37.9, 10.6, and 7.6\%, respectively. ${ }^{10}$ Rates of detection of M. genitalium have been reported higher in MSM population who are HIV-positive. ${ }^{11}$ Therefore, attention should be paid to these infections among MSMs, especially bisexuals, which might have critical implications not only for effective HIV/STD control but also for obstetric and gynecological complications in female partners. 


\section{Conclusion}

To our knowledge, this is the first report of coinfection with $C$. trachomatis, M. hominis, M. genitalium, and Ureaplasma spp. in an HIV-positive MSM. This case underscores the importance of testing both genital and extragenital sites in MSMs for $C$. trachomatis and genital mycoplasmas. Timely testing can result in early initiation of targeted interventions and along with behavioral counseling can in turn help in reducing STI burden by breaking the chain of transmission.

\section{Conflict of Interest}

None.

\section{Acknowledgement}

We thank Manoj Kumar for his technical assistance.

\section{References}

1 Ghys PD, Fransen K, Diallo MO, et al. The associations between cervicovaginal HIV shedding, sexually transmitted diseases and immunosuppression in female sex workers in Abidjan, Côte d'Ivoire. AIDS 1997;11(12):F85-F93

2 Ghosh A, Rawre J, Khanna N, Dhawan B. Co-infections with Ureaplasma parvum, Mycoplasma hominis and Chlamydia trachomatis in a human immunodeficiency virus positive woman with vaginal discharge. Indian J Med Microbiol 2013;31(2):190-192

3 Del Prete R, Ronga L, Lestingi M, et al. Simultaneous detection and identification of STI pathogens by multiplex real-time PCR in genital tract specimens in a selected area of Apulia, a region of Southern Italy. Infection 2017;45(4):469-477

4 Kokkayil P, Rawre J, Malhotra N, Dhawan B. Co-infection of Mycoplasma genitalium and Chlamydia trachomatis in an infertile female patient with genital tuberculosis. Indian J Pathol Microbiol 2013;56(4):457-459

5 Verma RK, Collumbien M. Homosexual activity among rural Indian men: implications for HIV interventions. AIDS 2004;18(13):1845-1847

6 Foschi C, Gaspari V, Sgubbi P, Salvo M, D'Antuono A, Marangoni A. Sexually transmitted rectal infections in a cohort of 'men having sex with men' J Med Microbiol 2018;67(8):1050-1057

7 Workowski KA, Bolan GA; Centers for Disease Control and Prevention. Sexually transmitted diseases treatment guidelines, 2015. MMWR Recomm Rep 2015;64(RR-03) :1-137

8 Kong F, Ma Z, James G, Gordon S, Gilbert GL. Species identification and subtyping of Ureaplasma parvum and Ureaplasma urealyticum using PCR-based assays. J Clin Microbiol 2000;38(3):1175-1179

9 Ollikainen J, Heiskanen-Kosma T, Korppi M, Katila ML, Heinonen K. Clinical relevance of Ureaplasma urealyticum colonization in preterm infants. Acta Paediatr 1998;87(10):1075-1078

10 Pépin J, Sobéla F, Deslandes S, et al. Etiology of urethral discharge in West Africa: the role of Mycoplasma genitalium and Trichomonas vaginalis. Bull World Health Organ 2001;79(2):118-126

11 Soni S, Alexander S, Verlander N, et al. The prevalence of urethral and rectal Mycoplasma genitalium and its associations in men who have sex with men attending a genitourinary medicine clinic. Sex Transm Infect 2010;86(1):21-24 